Laporan Kasus

\title{
Penanganan mikrotia bilateral: laporan kasus berbasis bukti
}

\author{
Dini Widiarni Widodo, Harim Priyono, Irma Suryati \\ Departemen Ilmu Kesehatan Telinga Hidung Tenggorok-Bedah Kepala Leher \\ Fakultas Kedokteran Universitas Indonesia - Rumah Sakit Dr. Cipto Mangunkusumo
}

Jakarta

\begin{abstract}
ABSTRAK
Latar Belakang: Mikrotia didefinisikan sebagai daun telinga berukuran kecil dengan insiden sekitar 1 dari 7000-8000 ribu kelahiran, dengan insiden pada satu telinga sekitar empat kali lipat lebih banyak dibanding dua telinga. Rekonstruksi mikrotia merupakan salah satu prosedur cukup sulit pada bidang plastik rekonstruksi. Saat ini, penggunaan tandur tulang rawan iga autologus masih menjadi baku emas untuk rekonstruksi mikrotia. Tujuan: mengingatkan kembali para ahli THT tentang pertimbangan pemilihan rekonstruksi bersamaan pada kasus mikrotia bilateral dengan pencarian literatur berbasis bukti. Kasus: dilaporkan satu kasus mikrotia bilateral derajat 3, dengan hantaran tulang telinga kanan $60 \mathrm{~dB}$, dan hantaran tulang telinga kiri 72,5 dB. Dengan pertimbangan memilih rekonstruksi bersamaan atau bertahap pada kedua telinga dan mengetahui prediksi perbaikan fungsi pendengarannya. Penatalaksanaan: aurikuloplasti tahap 1 dilakukan bersamaan pada kedua telinga. Skor Jahrsdoefer kedua telinga masing-masing 3 dan karena keterbatasan ekonomi dianjurkan menggunakan alat bantu dengar bukan BAHA untuk mengatasi hambatan komunikasi. Kesimpulan: penatalaksanaan mikrotia bilateral di bidang THT tidak hanya mencakup aspek rekonstruksi bentuk namun menekankan fungsi telinga sebagai alat berkomunikasi yang optimal.
\end{abstract}

Kata kunci: mikrotia bilateral, ambang pendengaran, aurikuloplasti.

\begin{abstract}
Background:Microtia is defined as small sized ear with incidence approximately 1 in 7000-8000 births, which incidents in one ear is 4 times more compared to bilateral ear. Microtia reconstruction is one of difficult procedures in plastic reconstruction field. Recently, the use of rib cartilage autograft is still the gold standard for ear reconstruction. Purpose: to inform otorhinolaryngologist concerning simultaneous ear reconstruction in bilateral microtia case with evidence based method. Case: a third grade bilateral microtia, with the result of bone conduction are $60 \mathrm{~dB}$ for right ear dan 72,5 dB for left ear, the consideration to reconstruct both ear simultaneously or gradually, and how to predict the hearing improvement Management: first step of auriculoplasty was done in both ears, with Jahrsdoefer score is 3 for each ear, BAHA is adviceable but due to economic limitation the patients chose hearing aids. Conclusion: Bilateral microtia management in otorhinolaryngology does not only emphasize on ear reconstruction aspects but also to restore ear function as a means of optimal communicating.
\end{abstract}

Keywords: bilateral microtia, hearing thresholds, auriculoplasty.

Alamat korespondensi: Dini Widiarni, e-mail: dini_pancho@yahoo.com 


\section{PENDAHULUAN}

Mikrotia didefinisikan sebagai daun telinga yang kecil dengan insiden sekitar 1 dari 7000-8000 ribu kelahiran. Mikrotia lebih sering terjadi pada telinga kanan dengan rasio sekitar 3:2, lebih sering pada laki-laki daripada perempuan (3:2), kasus lebih sering terjadi pada salah satu telinga daripada kedua telinga dengan perbandingan 4:1. Mikrotia disebabkan oleh faktor genetik dan faktor lingkungan, bukan suatu kelainan kromosom. ${ }^{1}$

Teratogen yang paling sering menyebabkan kelainan mikrotia seperti isotretionin, thalidomide dan infeksi rubella pada masa kehamilan. $^{1-3}$

Rekonstruksi mikrotia merupakan salah satu prosedur yang sulit pengerjaannya pada bidang plastik rekonstruksi. Rekonstruksi telinga dengan tulang rawan iga autologus atau dengan polietilen hasilnya tetap saja tak seindah daun telinga yang menggunakan prostesa. Saat ini, penggunaan tulang rawan iga autologus masih menjadi baku emas untuk rekonstruksi telinga. Berbagai teknik baru telah dikembangkan, di antaranya penggunaan implan dari aloplastik, prostesa dan pengembangan jaringan (tissue expander). ${ }^{1-3}$

Menurut $\mathrm{Wu} \mathrm{dkk}^{4}$ rekonstruksi telinga membutuhkan 4 kali operasi dengan jarak antar operasi minimal 6 bulan, sehingga total proses rekonstruksi telinga memakan waktu selama 2 tahun. Berbagai macam teknik operasi untuk rekonstruksi mikrotia, di RSCM lebih sering menggunakan teknik Nagata, dimana proses rekonstruksi telinga dipersingkat menjadi 2 tahap. Hal ini memberikan keuntungan untuk pasien karena akan mempercepat waktu rekonstruksi yaitu rekonstruksi tahap ke-2 dilakukan 12 minggu setelah tahap 1.2-5

Pengukuran terhadap bentuk daun telinga dapat dilakukan dengan menggunakan kaliper geser. Posisi kepala subjek yang dilakukan pemeriksaan harus tegak lurus menghadap ke depan sesuai garis horizontal Frankfurt.
Terdapat 8 pengukuran antropometri pada daun telinga yaitu panjang dan lebar daun telinga, panjang dan lebar lobul, panjang dan lebar konka, penonjolan telinga setinggi superaurale dan setinggi tragus. ${ }^{10}$

Posisi daun telinga diukur dengan menarik garis imajiner yang dibuat dari ujung atas dan ujung bawah daun telinga ke arah wajah. Seperti yang dikutip dari Widiarni $\mathrm{dkk},{ }^{10}$ yang menyebutkan bahwa ujung atas telinga dapat berada di atas alis mata, sejajar alis mata, dan sejajar dengan kelopak mata bagian atas atau sejajar dengan sudut mata. Ujung bawah telinga dapat berada di atas puncak cuping hidung, sejajar cuping hidung, sejajar puncak bibir atas, sejajar sudut bibir. ${ }^{10}$

Posisi daun telinga juga ditentukan oleh letak liang telinga. Berdasarkan Leiber, pertama ditarik garis imajinasi yang menghubungkan glabella dengan puncak bibir atas. Kedua, ditarik garis dari arah liang telinga ke arah garis pertama sampai membentuk sudut 90 derajat. ${ }^{10}$

Klasifikasi deformitas daun telinga menurut Aguilar dan Jahrsdoefer pada tahun 1988 dan masih digunakan hingga saat ini sebagai berikut: derajat 1 yaitu telinga normal, derajat II yaitu telinga dengan kekurangan struktural, misalnya tidak adanya skapa, tidak terbentuknya lobul, tidak ditemukannya konka atau tidak adanya lipatan antiheliks, dan derajat III yaitu telinga dengan gambaran klasik deformitas bentuk kacang tanpa adanya struktur telinga yang dapat dikenali dan anotia. ${ }^{8,11}$

Terdapat 3 pilihan rekonstruksi mikrotia: tandur autologus, rangka telinga aloplastik, prostesis. ${ }^{11}$

Rekonstruksi autologus, seperti pada teknik 4 tahap Brent dan teknik 2 tahap Nagata yang menggunakan tulang rawan iga untuk membangun framework daun telinga. Pada rekonstruksi dengan rangka alloplastik, framework yang digunakan berupa porous polyethilen $\left(\right.$ Medpor $\left.^{\mathbb{R}}\right)$. Penggunaan Medpor ${ }^{\mathbb{B}}$ baik karena biokompabiltasnya, stabilitas, integrasinya 
dengan jaringan hidup, dan tahan terhadap infeksi. Rekonstruksi dengan implan titanium berfungsi menghubungkan prostesis dengan tulang temporal namun hal ini menjadi pilihan kedua setelah rekonstruksi menggunakan autologus dan Medpor $^{\circledR B}$ gagal. $^{4,11-13}$

\section{TELAAH LITERATUR BERDASARKAN TINDAKAN BEDAH BERBASIS BUKTI}

\section{Pertanyaan Klinis}

Pasien dengan mikrotia bilateral disertai hantaran tulang telinga kanan sebesar $60 \mathrm{~dB}$ dan hantar tulang telinga kiri sebesar $72,5 \mathrm{~dB}$, manakah yang lebih baik dilakukan rekonstruksi aurikuloplasti tahap 1 dilakukan bersamaan di kedua telinga dibandingkan dengan satu telinga, dan bagaimana pengelolaan terbaik pada fungsi pendengaran pasien mikrotia bilateral ?

\section{Metode Pencarian Literatur}

Untuk pertanyaan klinis pertama strategi pencarian literatur dengan search engine PUBMED dan HIGHWIRE dengan kata kunci: "bilateral microtia" AND "auricle surgery" pada 5 tahun terakhir penerbitan jurnal (2007-2012).

Untuk pertanyaan klinis kedua, metode pencarian literatur menggunakan search engine PUBMED dan HIGHWIRE dengan kata kunci: "bilateral microtia" AND "hearing aid" pada 5 tahun terakhir penerbitan jurnal (2007-2012).

\section{LAPORAN KASUS}

Dilaporkan kasus anak perempuan usia 15 tahun dengan mikrotia dan atresia liang telinga bilateral mengeluhkan gangguan pendengaran, namun masih dapat memahami pembicaraan dengan melihat gerak bibir. Saat kasus ini ditemukan, pasien bersekolah di Sekolah Menengah Pertama dan sedikit mengalami hambatan dalam kegiatan akademis.

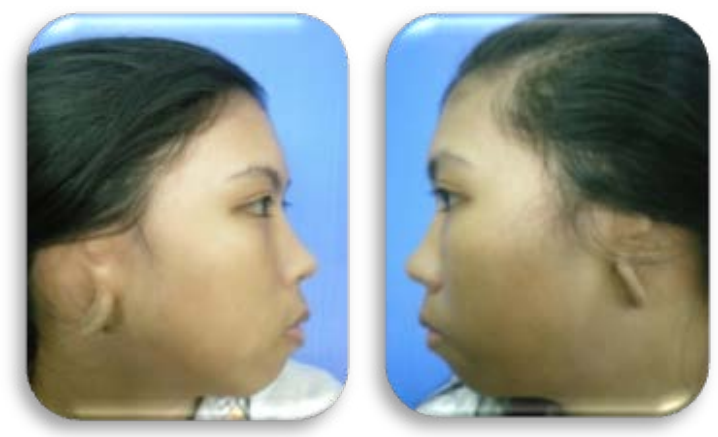

Gambar 1. Kasus pasien mikrotia derajat 3 bilateral

Pemeriksaan tomografi komputer mastoid didapatkan mikrotia dengan kanalis akustikus eksternus tidak tervisualisasi, kanalis akustikus internus tak tampak melebar ataupun tertutup. Membran timpani kanan dan kiri tak tervisualisasi, tulang pendengaran tervisualisasi dengan baik, koklea dan kanalis semisirkularis tampak jelas. Hantaran tulang telinga kanan sebesar $60 \mathrm{~dB}$ dan hantar tulang telinga kiri sebesar 72,5 dB.

Pasien menjalani aurikuloplasti tahap 1 pada kedua telinga dengan graft iga $6,7,8$ sisi kanan pada tanggal 23 Juli 2012, iga yang sudah diambil kemudian dibentuk rangka telinga (framework) sesuai pola telinga ibu pasien.

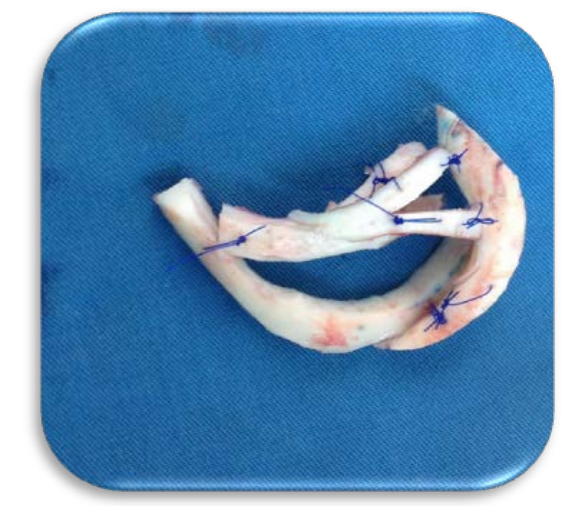

Gambar 2. Framework untuk aurikuloplasti

Rangka telinga ditanam pada daerah retroaurikuler telinga kanan dan dilanjutkan transposisi lobul telinga serta pemasangan haemovac $100 \mathrm{cc}$ sebagai drainase. Rangka telinga difiksasi menggunakan 
benang prolene putih. Hal yang sama dilakukan pada telinga sisi kiri.

Pasien dirawat selama 5 hari untuk evaluasi graft yang ditanam pada retroaurikuler (seperti hematoma, tanda-tanda nekrosis, tanda-tanda ekstrusi dari rangka telinga). Pada hari ke 22 pasca operasi, tidak ditemukan hiperemis, tanda-tanda nekrosis, tulang rawan yang terpapar dari kedua graft, jahitan tampak kering kemudian dilakukan pengangkatan jahitan di kedua telinga.

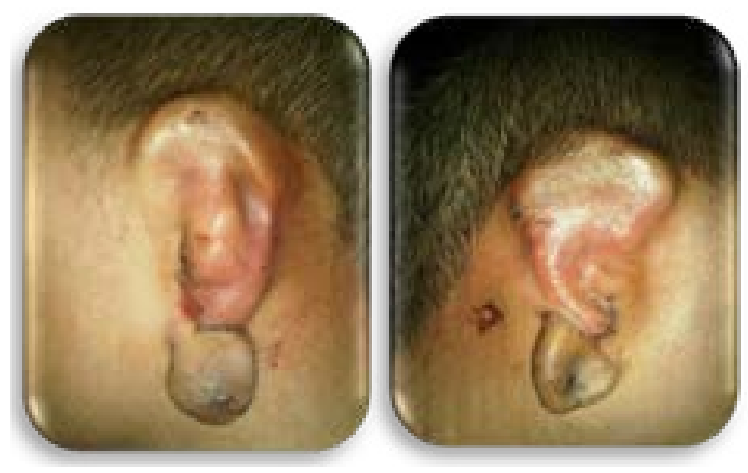

Gambar 3. Hasil aurikuloplasti tahap 1 pada kasus

Pasien dikonsulkan ke Otologi untuk rencana kanaloplasti atau meatoplasti, namun skor Jahrsdoefer telinga kanan dan kiri masing-masing 3, diputuskan dilakukan meatoplasti.

Aurikuloplasti tahap 2 dan meatoplasti dikerjakan pada Februari 2013, alat bantu dengar dipasang pada Juli 2013 ketika pasien memutuskan untuk melanjutkan bersekolah di Sekolah Menengah Kejuruan bagian pemasaran.
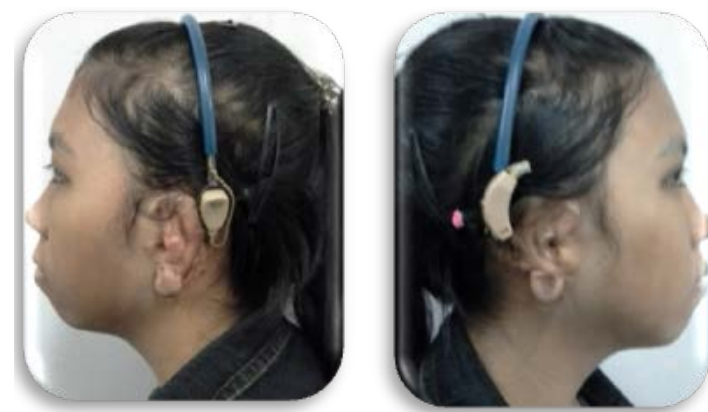

Gambar 4. Setelah aurikuloplasti tahap 2, tampak pasien menggunakan alat bantu dengar
Sejak menjalani seluruh tahapan aurikuloplasti dan menggunakan alat bantu dengar, pasien merasa prestasi sekolah meningkat karena dapat berkomunikasi dengan lancar tanpa membaca gerak bibir lawan bicaranya dan memiliki banyak kenalan karena lebih percaya diri.

\section{DISKUSI}

Pada kasus ini diketahui pasien perempuan, pada beberapa literatur disebutkan insiden mikrotia pada anak lakilaki sekitar 1,5 kali lebih sering dari anak perempuan. Namun di Cina jenis kelamin tak mempengaruhi distribusi kejadian mikrotia. Mikrotia bilateral prevalensinya sekitar 10\% atau sekitar 79-93\% kasus pada mikrotia unilateral. ${ }^{1,6}$

Pemeriksaanfisikkeduatelingadidapatkan tampak gambaran klasik deformitas seperti kacang, menurut klasifikasi Aguilar dan Jahrsdoefer tergolong mikrotia grade III. Dilakukan rekonstruksi teknik Nagata, tahap 1 yaitu pembentukan framework dengan menggunakan tulang rawan iga ke6,7,8 sisi kanan sekaligus mentransposisi lobul. Sedikit berbeda yang dilakukan oleh Liu $\mathrm{dkk}^{14}$ menggunakan tulang rawan iga autologus untuk membentuk 2 bingkai telinga dengan pola telinga yang sama, mereka menggunakan teknik tissue expander agar kulit dapat dipersiapkan sebagai flap dan graft sebagai pelengkap rekonstruksi telinga yang dilakukan melalui 3 tahap. Teknik rekonstruksi terdiri dari: "perluasan" daerah post aurikula menggunakan tissue expanders bentuk ginjal, membentuk bingkai telinga dari iga 6-8 lalu ditanam dibawah kulit yang telah "diperluas" tadi, dan tahap 3 yaitu mempercantik telinga yang direkonstruksi, membentuk konka agar tampak lebih cekung, rekonstruksi tragus dan pengangkatan sisa telinga yang abnormal. ${ }^{14}$ 
Menurut Liu dkk ${ }^{14}$ metode rekonstruksi telinga yang paling sering digunakan adalah Brent dan Nagata, dan penggunaan tulang rawan iga autograft sebagai bahan pembentuk bingkai telinga sangat menguntungkan karena mengecilkan angka kejadian infeksi, saat pembentukan bingkai telinga juga lebih mudah, terhindar dari reaksi penolakan tubuh terhadap jaringan asing yang masuk serta toleransi telinga terhadap tekanan jangka panjang yang cukup baik. Dapat disimpulkan bahwa rekonstruksi daun telinga penderita mikrotia bilateral dapat dilakukan bersamaan untuk mempersingkat waktu rekonstrusi dan biaya pasien.

Liu $\mathrm{dkk}^{14}$ berpendapat melakukan rekonstruksi telinga mikrotia bilateral secara bersamaan pada kedua telinga dapat menghemat waktu dan biaya yang dikeluarkan pasien, karena rekonstruksi 1 telinga mikrotia dapat memakan waktu sekitar 2,5 jam namun apabila dilakukan secara simultan rekonstruksi dapat berjalan hanya 4 jam. Pemilihan pola telinga dapat menggunakan contoh bentuk telinga orang tua pasien karena anak secara genetik memiliki bentuk telinga yang hampir mirip dengan orang tuanya. ${ }^{14}$

Menjawab pertanyaan klinis kedua, dalam kasus diputuskan melakukan meatoplasti karena nilai Jahrsdoefer 3. Nilai Jahrsdoefer ditentukan berdasarkan gambaran tomografi komputer mastoid, penilaian meliputi adanya stapes ( 2 poin), dan masing-masing bernilai 1 bila terdapat: tingkap lonjong, aerasi kavum timpani, saraf fasialis, kompleks maleus-inkus, pneumatisasi yang baik pada mastoid, terdapat hubungan inkus dan stapes, adanya liang telinga, stenosis liang telinga namun maleus tervisualisasi. Skor maksimal adalah 10, kanaloplasti dilakukan bila nilai Jahrsdoefer $\geq 8$, namun bila skor $\leq 5$ maka meatoplasti menjadi pilihan. ${ }^{12}$

Renee $\mathrm{dkk}^{15}$ dalam sistematik review melaporkan bahwa pasien dengan tuli konduktif bilateral yang dilakukan pemasangan BAHA dikedua telinga memiliki keuntungan lebih banyak secara objektif dan subjektif dibandingkan yang menggunakan BAHA 1 sisi. Keuntungan penggunaan BAHA di kedua telinga antara lain adanya peningkatan sensitifitas anak saat mendengarkan suara dalam suasana hening, terjadi perbaikan secara perlahan terhadap persepsi kosa kata saat bicara, meningkatnya kemampuan persepsi anak saat bicara di tempat bising kecuali arah datangnya suara berasal dari pada telinga kontralateral, meningkatnya ketajaman dalam melokalisir dan lateralisasi sumber suara, meningkatnya kualitas persepsi suara dan kualitas hidup. BAHA tetap merupakan pilihan utama namun pada kasus ini sukar dilakukan akibat keterbatasan kemampuan ekonomi keluarga, sehingga pilihan lain yaitu pemasangan alat bantu dengar. Pasien mengalami kemajuan emosional berupa meningkatnya kepercayaan diri sebagai remaja karena telah memiliki daun telinga dan prestasi sekolah meningkat akibat meningkatnya kemampuan berkomunikasi. Berdasarkan diagram yang dibuat Frenzel $\mathrm{dkk}^{16}$ ternyata penggunaan alat bantu dengar yang diberikan pada usia dini (dibawah 1 tahun) kelak dapat membantu anak belajar berkomunikasi dengan optimal. ${ }^{16}$

Dari kasus ini dapat disimpulkan bahwa dalam rekonstruksi mikrotia bilateral dapat dikerjakan bersamaan di kedua telinga karena hal ini dapat menghemat waktu dan biaya serta mengurangi lamanya angka kesakitan pasien dibandingkan rekonstruksi satu per satu, dan pemilihan alat bantu dengar sebagai pengganti BAHA dapat pula dipertimbangkan bila terdapat hambatan biaya. Tujuan utama rekonstruksi telinga yaitu meningkatkan kualitas hidup pasien dengan meningkatkan kemampuan berkomunikasi dan kepercayaan diri. 


\section{DAFTAR PUSTAKA}

1. Yazdi AK, Hosseini MS, Sadeghi M, Sazgar AA, Safikhani R. Comparison of microtia reconstructive with autograft versus homograft. Arch Iranian Med $2007 ; 10: 43-7$.

2. Jiang H, Bo Pan, Zhao Y, Lin L, Lei Liu, Zhuang H. A 2-stage sar reconstruction for mikrotia. Arch Facial Plast Surg 2011; 13:162-6.

3. Tollefson TT. Advances in the treatment of microtia. Curr Opin Otolaryngol Head Neck Surg 2006; 14:412-22.

4. Wu J, Zhang R, Zhang Q, Xu Zhicheng, Chen W, Li D. Epidemiological analysis of microtia: a retrospective study in 345 Patients. Int J Pediatr Otorhinolaryngol 2010; 74:275-8.

5. Widodo DW. Pengaruh fibrin glue dan demineralized bone matrix terhadap keberhasilan tandur artilago autologous pada aurikuloplasti penderita mikrotia. Disertasi. Jakarta: Pasca Sarjana Universitas Indonesia; 2010. p.1-37.

6. Alasti F, Camp GV. Genetics of microtia and associated syndromes. J Med Genet 2008; 46:361-85.

7. Wareing MJ, Lalwani AK, Jackler RK. Development of the ear. In: Bailey BJ, Johnson JT, Newlands SD, editors. Head \& Neck Surgery Otolaryngology $4^{\text {th }}$ ed. USA: Lippincott Williams \& Wilkins; 2006. p.1870-80

8. Aguilar III EA. Congenital auricular malformation. In: Bailey BJ, Johnson JT, Newlands SD, editors. Head \& Neck Surgery Otolaryngology $4^{\text {th }}$ ed. USA: Lippincott Wiliams \& Wilkins; 2006. p. 2686-700.

9. Ruder RO. Congenital malformation of the auricle. In: Papel ID, Frodel J, Park SS, Holt GR, Sykes JM, Larrabee WF, Toriumi D, Nachlas N, editors. Facial Plastic and Reconstructive Surgery. $2^{\text {nd }}$ ed. New York: Thieme; 2002. p.803-12

10. Widiarni D, Trimartani, Wicaksono A. Antropometri telinga sebagai dasar diagnosis dan perencanaan rekonstruksi kelainan daun telinga. ORLI 2009; 39(2):51-63.

11. Thorne $\mathrm{CH}$. Otoplasty and ear reconstruction. In: Thorne $\mathrm{CH}$, Beasley SW, Aston SJ, Bartlett SP, Gurtner GC, Spear SL, editors. Grabb's and Smith Plastic Surgery. $6^{\text {th }}$ ed. USA: Lippincott Williams \& Wilkins; 2007. p.297-312.

12. Ha RY, Trovato MJ. Plastic surgery of the ear. Dallas: University of Texas Southwestern Medical, 2011.p.1-52

13. Romo T, Reitzen SD. Aesthetic microtia reconstruction with medpor. Facial Plast Surg 2008; 24:120-8. 